\title{
Sangue e suas partículas: sobre a não homogeneidade fluídica do sangue no parentesco ${ }^{1}$
}

Juliana P. Lima Caruso ${ }^{2}$ Lapod/Hybris/USP

Resumo: Neste artigo, a partir das teorias do parentesco pretendo propor algumas questões sobre sangue, substâncias e relações de parentesco, comparando duas pesquisas distintas. Com isto, pretendo abordar algumas das principais questões que a categoria substância - em especial, o sangue - suscita nos estudos antropológicos e de parentesco. Parte da reflexão inclui pensar a categoria sangue de maneira mais ampla, considerando tanto a sua representação enquanto um elemento quanto a soma de múltiplos componentes. Estes diversos elementos e fragmentos, pensados na categoria sangue, alimentam a discussão sobre a não homogeneidade das/nas substâncias que compõe o parentesco, que circulam ou fazem parte do sangue. Trata-se de um debate inicial que, através do sangue, permite colocar em diálogo autoras como Carsten (2011) e Héritier (1996) proporcionando uma discussão que compreenda diferentes visões no parentesco

Palavras-chave: sangue; parentesco; substância; genética. 


\title{
Blood and its particles: about the fluidic non-homogeneity of blood in kinship
}

\begin{abstract}
In this article, within the theories of kinship framework, I intend to propose some questions about blood, substances and kinship relations, comparing two different researches. In doing so, I intend to address some of the main issues the substance category - in particular, blood - raises in anthropological and kinship studies. Part of this reflection includes thinking about the blood category more broadly, considering both its representation as an element and as the sum of multiple components. These various elements and fragments, thought of within the blood category, feed into the discussion about the non-homogeneity of/in the substances that make up kinship relations, which circulate or are part of the blood. It is an initial debate that, through blood, allows to put in dialogue authors like Carsten (2011) and Héritier (1996), providing a discussion that comprehends different views on kinship.
\end{abstract}

Keywords: blood; kinship; substance; genetics.

\section{Sangre y sus partículas: sobre la falta de homogeneidad fluida de la sangre en el parentesco}

Resumen: En este artículo pretende a partir de las teorías del parentesco, y de la comparación dos investigaciones diferentes, plantear algunas cuestiones sobre sangre, sustancias y relaciones de parentesco. Con esto, busco abordar algunas de las principales cuestiones que plantea la categoría de sustancias, especialmente la de sangre, en los estudios antropológicos y de parentesco. Parte de la reflexión incluye pensar en la categoría de sangre de manera amplia, considerando tanto su representación como elemento único, como hecho de múltiples componentes. Esta diversidad de elementos y fragmentos, que surgen a través de la reflexión de la categoría sangre, alimentan la discusión sobre la falta de homogeneidad en las sustancias que componen las relaciones de parentesco, que circulan y forman parte de ella. Intento entonces generar un debate inicial que, a través de la sangre, permite poner en diálogo a autores como Carsten (2011) y Héritier (1996), proporcionando una discusión que comprende diferentes visiones del parentesco.

Palabras clave: sangre; parentesco; sustancia; genética. 
$\mathrm{A}$ ntes do advento da genômica, da genética molecular e da epigenética, entre as expressões mais vernaculares para se referir às relações de parentesco e de filiação estavam - e ainda se fazem presentes em muitos lugares - frases como "ela/ele é sangue do meu sangue/corre o mesmo sangue em nossas veias". Como Howell (2009) notou, em seu estudo sobre imigrantes e crianças imigrantes adotadas na Noruega, as expressões relacionando sangue e parentesco são encontradas em muitos países europeus. Para a autora, tais sentenças estão atreladas ao "parentesco euro-americano" - seguindo a definição de Schneider (1968/2016) - que "é bem conhecido pelo lugar essencial que ele reserva à metáfora do sangue" 3 . Talvez hoje, pouco a pouco, expressões como "herdou meus genes", "parecem clones" ou "temos o mesmo DNA" comecem a ganhar mais o espaço que precedentemente pertencia apenas ao "sangue como a dimensão biológica da filiação" (NICOLAS et al., 2007: 5). Esta dimensão biológica da filiação tem o sangue como metáfora e idioma. Uma metáfora que em parte não é, e talvez não será totalmente, substituída pela alusão às novas tecnologias biomédicas para as relações de filiação e parentesco, mas que pode inspirar metáforas e alusões trazidas pela genética. Idioma este que também se aplica nas relações e terminologias de parentesco, através do sangue e de suas relações bastante atreladas às concepções ditas ocidentais, judaico-cristãs que aparecem desde o início nos estudos de parentesco4, como em Systems of Consangunity and Affinity of the Humain Family, de Morgan (1871).

Parte substancial da análise de Schneider (2016) sobre as representações euroamericanas do parentesco toca nesta base "ocidental" e "biológica" imputada às relações de parentesco. Tendo o sangue como um dos principais expoentes, o autor nos chama a atenção, através das terminologias do parentesco americano, para a proeminência do sangue e da noção de consanguinidade no vocabulário e nas formas de classificação das relações de parentesco.

Para o autor, o sangue é um divisor dentro do parentesco americano: "A regra é muito simples. Uma pessoa é um parente se ela for relacionada por sangue ou por casamento, e se essa relação for próxima o suficiente (ou não for distante demais) (SCHNEIDER, 2016: 74)”. Assim, as relações são separadas entre aquelas por afinidade, criadas a partir do casamento e aquelas resultantes do compartilhamento do sangue, que contam com supostos vínculos biológicos. Sendo a "voz do sangue" uma maneira de designar e compreender as relações de parentesco, esta relação também designa outro aspecto: "relação de sangue é, portanto, uma relação de substância, de material biogenético compartilhado" (SCHNEIDER, 2016: 38). No entanto, como bem ressalta Schneider: "[A categoria sangue] não apenas significa a coisa vermelha que corre nas veias, mas também a combinação

\footnotetext{
3 Tradução do autor: «La parenté euro-américaine est bien connue pour la place essentielle qu'elle accorde à la métaphore du sang» (HOWELL, 2009: 331)

4 Importante sublinhar, como bem nos lembra Eideiman (2007) que os "fundadores" da disciplina e dos estudos de parentesco sustentavam importantes discussões sobre o caráter biológico ou social do parentesco: " Se todos os fundadores da antropologia do parentesco concordam em fazer desta área um domínio social a parte, a oposição é forte entre aqueles que pretendem cortar radicalmente o caráter biológico da reprodução humana (como Émile Durkheim ou William Rivers), aqueles que a entendem como expressão direta do reconhecimento dos laços de sangue (como Lewis Morgan), ou ainda, aqueles que a consideram como interpretação cultural dos fatos biológicos (como Bronislaw Malinoski). [Tradução do autor] «Si tous les fondateurs de l'anthropologie de la parenté s'accordent à faire de cette dernière un domaine social à part, l'opposition est forte entre ceux qui entendent la couper radicalement du caractère biologique de la reproduction humaine (comme Émile Durkheim ou William Rivers), ceux qui en font l'expression directe de la reconnaissance des liens du sang (comme Lewis Morgan), ou encore ceux qui la considèrent comme l'interprétation culturelle de faits biologiques (comme Bronislaw Malinowski).» (EIDEIMAN, 2007: 11)
} 
de substância e código de conduta que aqueles que compartilham a coisa vermelha, os parentes de sangue, devem ter" (SCHNEIDER, 2016: 123). Se o sangue tem seu lado metafórico, enquanto substância, para Schneider ele também pode ser uma "coisa material", sendo, por consequência, uma "entidade natural". Nos estudos de parentesco, os autores pós-schneiderianos passam a reservar uma atenção especial a substâncias, ampliando tanto a discussão sobre as relações que elas atravessam, assim como as que elas criam e transformam.

Diversas abordagens que relacionam substâncias e parentesco afloraram nas últimas décadas, sendo que nem todas estavam diretamente inspiradas pelo pensamento de Schneider. Em 2015, a partir de algumas questões encontradas numa pesquisa realizada durante $2013-2014$, iniciei 5 uma reflexão sobre a questão das substâncias no parentesco e alguns diálogos possíveis entre diferentes autores. Entre estes, Françoise Héritier (1996), e sua proposta de um incesto de segundo tipo, cuja principal característica, em oposição ao de primeiro tipo ${ }^{6}$ - além do fato deste não ser universal-, seria "a circulação de fluídos de um corpo a outro"7. Importa neste caso o fluído e o corpo. Os corpos que contenham o idêntico ${ }^{8}$ quando entram em contato, ou quando são colocados em conexão através de um terceiro, como no exemplo duas irmãs que compartilham um mesmo parceiro, são mais propensos aos perigos do incesto de segundo tipo. Este incesto vai além de uma proibição que recaí apenas sobre uma posição genealógica específica que impediria relações sexuais e matrimoniais com determinados parentes e engloba os "humores" dos corpos. Dos fluídos elencados pela autora, a partir de exemplos retirados da Bíblia, do Corão e da Talmud, assim como da sua etnografia entre os Samo, destacam-se o sangue, o leite e o esperma como possíveis causadores "do acúmulo de idênticos" justificando assim, as interdições matrimoniais que visam evitar essas e outras consequências (HÉRITIER, 1996: 276).

$\mathrm{Na}$ pesquisa mencionada, eu estava particularmente interessada na tríade "leite, sangue e esperma", que figuram como substâncias frequentemente citadas nos estudos de parentesco (HÉRITIER, 1996; STRATHERN, 2006; CARSTEN 2011a, 2011b; HUTCHINSON, 2000; HAMDANI, 2010; KLAPICH-ZUBER, 1984; FORTIER, 2001). O interesse naquela época - e ainda nos dias atuais - residia na busca por ampliar as possibilidades da abordagem sobre as substâncias, pensando a liquidez e a materialidade das substâncias discutidas nos estudos de parentesco.

Entre as propriedades das substâncias, como a materialidade, a liquidez e a transmissão, as pistas mais satisfatórias para pensá-las foram encontradas principalmente nos trabalhos de Janet Carsten (2001; 2011a; 2011b; 2013) que coloca frequentemente o sangue em questão e destaque em suas análises. Em Substance

\footnotetext{
5 Ver Caruso (2015), “Consubstancialidade, sangue e parentesco: algumas reflexões sobre as substâncias”. Congresso XI RAM (Reunion de Antropologia del Mercosur), Montevideo-Uruguai.

${ }^{6}$ Para Héritier, o incesto de primeiro tipo seria aquele definido por Claude Lévi-Strauss (2009/1949). Ver As Estruturas elementares do parentesco.

7 Héritier: "A existência de um incesto de segundo tipo nos leva a conceber a proibição do incesto como um problema de circulação de fluídos de um corpo a outro. O critério fundamental do incesto é colocar em contato humores idênticos". " $L$ 'existence d'un inceste de deuxième type nous conduit à concevoir la prohibition de l'inceste comme un problème de circulation de fluides d'un corps à l'autre. Le critère fondamental de l'inceste c'est la mise en contact d'humeurs identiques".) (HÉRITIER, 1994: 11, tradução do autor)

${ }^{8}$ Fine (2013) sintetiza o incesto de segundo tipo de Françose Heritier como: «A proibição do incesto se torna então um problema de circulação de fluídos entres os corpos, seu critério fundamental sendo o contato entre humores idênticos. Ter relações sexuais com a irmã da esposa é colocar em contato duas irmãs ao transportar os humores sexuais de uma ao útero da outra. Esta teoria afirma a primazia do simbólico. Simbólico ancorado naquilo que existe de mais físico na humanidade, à saber a diferença anatômica dos sexos". ( "La prohibition de l'inceste devient alors un problème de circulation des fluides entre les corps, son critère fondamental étant la mise en contact d'humeurs identiques. Avoir des relations sexuelles avec la sœur de sa femme, c'est mettre en contact les deux sœurs en transportant les humeurs sexuelles de l'une dans la matrice de l'autre. Cette théorie affirme le primat du symbolique, "symbolique ancré dans ce qu'il y a de plus physique dans l'humanité, à savoir la différence anatomique des sexes».) (FINE, 2013: 99, tradução do autor).
} 
and Relationality: blood in contexts, Carsten (2011b) nos convida a imaginar que, a priori, as substâncias podem ser todos os fluídos e tecidos corporais, abrindo um espaço para considerar ossos, unhas e cabelo como possíveis substâncias apesar de que, como a autora explica mais adiante em seu artigo, a materialidade das substâncias no parentesco está de certa maneira atrelada às noções de fluxo, transferência e da capa cidade de atravessar corpos, assim como os fantasmas. Isso significa uma guinada na abordagem das substâncias, já que a ampliação da materialidade e do que pode ser considerado substância permite até certo ponto repensar tanto como essas substâncias constroem e fazem parte das relações de parentesco. Ao mesmo tempo, nos alertam para os eventuais etnocentrismos realizados em nome delas. Como Olivier Allard (2006) aponta através da oposição entre o pensamento de Carsten e Godelier, existem diversas abordagens sobre as substâncias nos estudos de parentesco. Analisando os trabalhos de Carsten e Godelier, Allard comenta:

\begin{abstract}
Janet Carsten escolheu consagrar um capítulo de sua obra à noção de "substância" e aos papéis que ela desempenha no estudo do parentesco (pp.109-135), diferente de Maurice Godelier que não considera essa noção como problemática. Ela ressalta com fineza a diversidade de sentidos do termo na linguagem cotidiana, mas, igualmente nos trabalhos antropológicos - da "substância biogenética", fixa e permanente de David Schneider (1980) até a substância "fluida" e "maleável" da qual E. Valentine Daniel (1984) fala sobre a Índia. Observando os perigos que podem advir de tal variedade de significados, Janet Carsten considera que é precisamente a fonte da utilidade do termo, que desempenhou um papel fundamental na " transformação de características adquiridas em características dadas, e vice-versa" (p. 131), e que permitiu desestabilizar a oposição entre o biológico e o social (p. 133). (ALLARD, 2006: 13, tradução do autor) 9
\end{abstract}

Pode-se dizer que há certos riscos no emprego de forma engessada das substâncias - assim como de outras categorias - nos estudos parentesco. Isto é parte da crítica de Olivier Allard (2006) sobre a forma como alguns autores tratam as substâncias, sem um exame mais aprofundado da categoria e do lugar que ela ocupa nas relações de parentesco. Torna-se imperativo neste ponto pensar os caminhos e os possíveis equívocos que as abordagens e os usos da categoria substância podem levar e, ao mesmo tempo, as possibilidades que uma abordagem mais ampla poderia oferecer aos estudos de parentesco.

Longe de estar próxima de sair desse labirinto no qual as substâncias e, em especial, o sangue nos colocam, gostaria de refletir neste artigo sobre a homogeneidade e não homogeneidade fluídica das substâncias, em especial do sangue. Através do sangue, pretendo observar as relações que fragmentos e partículas que o compõe ou veiculam nesta substância poderiam contribuir para ampliar os debates no campo do parentesco. Esta ampliação da substância a partir de seus múltiplos componentes é também uma tentativa de refletir sobre os pequenos ou microscópicos - até invisíveis - elementos que compõe as substâncias e consequentemente, as relações de ancestralidade e parentesco, trazidos também pelas novas tecnologias genéticas. Para abordar este assunto, pretendo discutir a partir de duas pesquisas diferentes que, de formas diversas, fundamentaram o questionamento sobre a não-homogeneidade fluídica do sangue. A primeira pesquisa, de

\footnotetext{
9 "Janet Carsten choisit de consacrer un chapitre de son ouvrage à la notion de « substance » et aux rôles qu'elle a joués dans l'étude de la parenté (pp. 109-135), contrairement à Maurice Godelier qui ne considère pas cette notion comme problématique. Elle souligne avec finesse la diversité des acceptions du terme dans la langue courante, mais également dans les travaux anthropologiques - de la « substance biogénétique », fixe et permanente, de David Schneider (1980), jusqu’à la substance «fluide » et « malléable » dont parle E. Valentine Daniel (1984) à propos de l'Inde. Tout en relevant les dangers qui peuvent venir d'une telle variété de significations, Janet Carsten juge que c'est précisément la source de l'utilité du terme, qui a tenu un rôle clé dans la " transformation de caractéristiques acquises en caractéristiques données, et vice-versa » (p.131), et qui a permis de déstabiliser l'opposition entre le biologique et le social (p. 133). »
} 
doutorado ${ }^{10}$, foi realizada em sete comunidades tradicionais caiçaras e tratou das relações de parentesco e identidade, problematizando sobre o sangue e as substâncias que o compõe e que o utilizam como veículo. Já na segunda pesquisa, em curso, trata das relações de parentesco e de ancestralidade entre os moradores do sul e do sudeste brasileiro, portadores de uma variante genética patogênica específica, que podem desenvolver a síndrome de Li-Fraumeni. Deste projeto, pretendo relacionar a ideia de partículas, fragmentos e transmissão como componente ou como inter-relação com as substâncias, ampliando suas possibilidades de composição e decomposição do/no parentesco. Busco com isso, abrir espaço nas reflexões futuras para dialogar a partir dessa partição de substâncias com o parentesco e a ancestralidade.

A escolha do entrelaçamento desses dois exemplos foi de certa maneira inspirada nos trabalhos de Carsten, mais especificamente no artigo intitulado "La vie sociale du sang". Janet Carsten (2011a), neste texto, traz reflexões e exemplos etnográficos com os quais pretendo dialogar e que permitem pensar o sangue de maneira mais ampliada, suas possibilidades, homogeneidade e heterogeneidade, considerando as pequenas coisas que ele carrega.

\section{Coisas no sangue ou que fazem parte do sangue? 0 “carregado", os antídotos, o óleo e a mistura}

A doação de sangue em alguns hospitais na Malásia é o tema central retratado por Carsten (2011a) em "La vie sociale du sang". Neste trabalho, a autora pôde identificar que o sangue está relacionado a questões de identidade, de religião e de parentesco. Os dois casos relatados pela autora dizem respeito a pedidos específicos realizados por pacientes durante a transfusão de sangue.

No primeiro relato, ela aborda o pedido de alguns pacientes que, quando internados em um hospital, necessitando de uma transfusão de sangue solicitam o sangue de algum parente ou o próprio sangue que já tenham doado. A alegação, segundo a autora, era a de que existiria uma "janela de tempo" em que alguns vírus poderiam passar desapercebidos pelas equipes biomédicas. Este pedido, como mostra Janet Carsten (2011), está muito menos ligado a atitudes meramente profiláticas e talvez mais próximo das questões de parentesco, já que o sangue de um parente também estaria sujeito ao contágio. No segundo caso, a autora expõe uma questão bastante delicada que diz respeito aos pedidos de pacientes muçulmanos que preferem receber o sangue de doadores malaios (muçulmanos), garantindo assim o recebimento do sangue de um doador que não tivesse ingerido carne de porco ${ }^{11}$. Carsten relaciona certeiramente estas demandas a preocupações religiosas e identitárias, mas não posso me furtar de pensar o papel dessas partículas que entram no sangue ou que veiculam pelo sangue e que estão pelos corpos. Ingerir o porco é integrá-lo ao sangue ou é permitir que o sangue carregue partes dele? E receber o sangue de um não-parente, torna alguém menos

\footnotetext{
${ }^{10}$ A pesquisa de doutorado foi realizada dentro do programa de doutorado pleno no exterior da CAPES (Coordenação de Aperfeiçoamento de Pessoal de nível Superior), a qual eu agradeço por ter possibilitado a realização do doutorado na EPHE-École Pratique des Hautes Études, assim como do trabalho de campo para a tese intitulada : "De l' autre côté de l'île: parenté et identité dans sept communautés caiçaras du sud-est brésilien.".

11 "A questão de saber se pacientes muçulmanos podem ou não receber sangue de doadores não muçulmanos é particularmente sensível. Uma técnica de laboratório me disse que os malaios- que doam mais frequência nos hospitais públicos do que nos hospitais particulares- pediam muitas vezes serem transfundidos do sangue doado por malaios, por causa da proibição do consumo da carne de porco por muçulmanos. [Tradução do autor]. (Carsten, 2011:15) «La question de savoir si les patients musulmans peuvent ou non recevoir du sang de la part de non-musulmans est particulièrement sensible (Peletz 2002). Une laborantine me dit que les Malais - qui donnent plus souvent dans les hôpitaux publics que dans les hôpitaux privés - demandaient souvent à être transfusés avec du sang donné par des Malais, à cause de la prohibition de consommation du porc pour les musulmans ».
} 
familiar?

Durante a minha primeira pesquisa (CARUSO ,2017), encontrei uma situação que remetia aos questionamentos de Carsten sobre o sangue e na qual a presença do porco e de outros alimentos no sangue era importante. Esta primeira circunstância deu origem a reflexões sobre a não homogeneidade fluídica do sangue assim como o entendimento dessas pessoas sobre a fragmentação e a presença de outros componentes das/nas substâncias.

Ao longo do levantamento genealógico, algumas mulheres falavam sobre seus partos, comentando se eles tinham acontecido na localidade em que habitavam com o auxílio de alguma parteira ${ }^{12}$ (na época, apenas duas parteiras estavam vivas e, devido à idade avançada, já não faziam mais partos) ou se os partos ocorreram em hospitais de forma natural ou cesariana. Interessada nestas experiências e na relação das interlocutoras com a biomedicina, comecei a perguntar mais sistematicamente sobre os partos e a conversar com as parteiras de duas comunidades. Foi durante a fala de Joaquina que outro aspecto ligado ao nascimento me chamou atenção. Joaquina, com seus quase 50 anos, contou-me que o parto dos primeiros filhos aconteceu em casa, com ajuda das parentes, mas que no último, devido a algumas complicações, teve que ir ao hospital. Além das violências obstétricas, Joaquina estava incomodada com o impedimento, ao longo de sua permanência no hospital de seguir a "dieta", leia-se as prescrições e restrições de alimentos classificados como "mansos" ou "fracos", que podem ser consumidos em todas as ocasiões, e os "carregados" ou "fortes" que, de maneira oposta, devem ser evitados em algumas circunstâncias.

É possível encontrar diversos trabalhos na Antropologia sobre interdições/tabus alimentares, principalmente sobre alimentos ditos "reimosos". São geralmente referenciados como práticas mais encontradas nas regiões norte, nordeste e central do Brasil, cujas interdições são indicadas tanto para o período do puerpério, ou "resguardo", como em outras situações de convalescença em homens, mulheres e crianças (MOTTA-MAUÉS e MAUÉS, 1978; CANESQUI, 1988; PEIRANO, 1975; SILVA, 2007; WOORTMAN, 2008). Seguindo esses autores, os alimentos reimosos estão em oposição aos mansos, e quando ingeridos nos períodos de doença e pós-parto podem causar efeitos nefastos diversos. Apesar da proximidade da noção de alimentos ditos reimosos, nas localidades estudadas encontrei algumas singularidades importantes. Além desses alimentos serem classificados principalmente como mansos/carregados, eles devem ser evitados de forma diferente entre o puerpério e outras situações de convalescença ${ }^{13}$.

Para mulheres, homens e crianças feridos ou enfermos, deve-se evitar a ingestão dos alimentos carregados pois podem agravar o quadro, infeccionar as feridas ou cortes (principalmente os cirúrgicos) e em alguns casos, causar diarreias. Já para as mulheres no puerpério, o consumo de tais alimentos pode levar ao "desmando", que me foi descrito como um tipo de hemorragia, na qual o sangue "vem todo para baixo". Além de evitar comer alimentos "carregados", deve-se consumir apenas os mansos. O interessante e diferente aqui é que, para algumas mulheres, tais alimentos devem ser ingeridos em uma determinada ordem a ser seguida para cada filho. Algumas mulheres chegam mesmo a anotar esta ordem como forma de não esquecê-la. Chantal, 38 anos, mantinha um pequeno caderno

\footnotetext{
${ }^{12}$ Algumas mulheres relataram terem recebido o auxílio de uma parente (consanguínea ou por aliança) ou contaram com a ajuda de uma vizinha. Em alguns desses casos, isso aconteceu pelo fato de suas comunidades não possuírem uma parteira e, em outros, foi uma escolha pessoal.

${ }^{13}$ É importante ressaltar que, com a regularidade das visitas de esquipes de saúde e do contato com biomédicos, as mulheres mais jovens que optam pelo parto em ambiente biomédico estão cada vez menos seguindo a dieta, transmitida pela mãe ou sogra, assim como outras restrições relacionadas ao período gestacional.
} 
onde ela anotava o que comeu para cada um dos 4 filhos. Sobre isso, propus que esse consumo alimentar no puerpério, obedecendo a mesma sequência para todos os filhos, poderia ser entendido como uma forma de reforçar substancialmente a construção da germanidade. Para outras mulheres, o importante era ingerir a carne de frango no primeiro dia, contando que, na hora em que entravam em trabalho de parto, alguém já se preparava para "matar a galinha" e que após, no segundo dia, comeriam um "peixinho manso". Somente depois de algumas semanas que os alimentos classificados como "carregados" 14 poderiam ser reintroduzidos gradualmente, de forma segura. Esta mesma reintrodução alimentar foi notada de maneira análoga por Mariza Peirano (1975) em seus estudos em uma comunidade de pescadores em Icaraí, no Ceará e por Raquel Scopel (2014), entre os Munduruku no estado do Amazonas.

Cada uma das sete comunidades estudadas apresentava divergências sobre quais peixes ou alimentos eram mais ou menos "carregados", diferenças que também podem se manifestar no interior de uma mesma localidade, variando de famílias para família. No entanto, a "lista" do que deve ser evitado era em geral uníssona. Os alimentos "carregados" são: carne de porco, peixes com dentes, peixes cuja carne tivesse muito sangue e alguns peixes com escamas, sendo os peixes espada, bonito, enchova e cação os mais citados. Frutos do mar, como camarão e lula, também são elencados como carregados, ao lado dos ovos (de galinha e pata) e da carne de pato. Quando questionados sobre o que seria o que o "carregado" em si, alguns interlocutores responderam que é uma espécie de óleo que entra no corpo e permanece no sangue, misturando-se a ele. Os efeitos adversos da presença do carregado no sangue das pessoas podem ser vistos através do próprio sangue ${ }^{15}$, como por exemplo o "desmando" que, nas mulheres, é descrito como uma hemorragia mortal.

Os peixes e as carnes consideradas carregadas possuem um traço em comum: são carnes descritas como contendo muito sangue, carnes "escuras" ou de animais cujos hábitos alimentares são carnívoros. Pode-se evitar o "desmando", fazendo uso de antídotos contidos no próprio alimento portador do "carregado": no caso dos peixes carregados, os ossos deles e outras partes sólidas devem ser torrados, transformados em pó e ingeridos. O mesmo se aplica para os ovos, cuja casca também passa por trituração após ser assada para ser consumida. As partes duras do ser devem ser fragmentadas e sofrerem fusão para adentrarem o corpo, podendo equilibrar ou neutralizar as porções moles e líquidas antes consumidas do mesmo e que se tornam perigosas à vida.

À primeira vista, não cabe olhar neste caso para os efeitos nefastos do contato e transmissão de substâncias a partir da perspectiva formulada por Françoise Héritier (1994) como a "mecânica dos fluídos" - como no problema do "acúmulo do idêntico" - apoiada em Aristóteles (HÉRITIER, 1994: 286-303). Não pelo esquema em si, mas por não contribuir a escapar do modelo da escola "hipocrática dos fluídos e dos humores"16, que fundamentou e, de acordo com Rezende

\footnotetext{
${ }_{14}$ Batistoni (2006), em sua pesquisa de Ecologia Humana realizada dez anos antes e em uma das comunidades por mim estudadas, também encontrou uma regularidade na lista dos alimentos considerados carregados.

15 Como Carsten (2011a: 24) nos lembra, o sangue tem "três características que favorecem sua extensão metafórica": 1"ele é visualmente impressionante"; 2-pode estar dentro e fora do corpo; 3- "pode ser associado à vida e a cessação dela". Além disso, em outro artigo, Carsten (2011b) atribuí ao sangue a possibilidade de que "algumas metáforas são mais metafóricas que outras". Dessa consideração, parte que o sangue tem uma "extensão metafórica por algumas características", tais como: sua "relação com a vitalidade"; um "papel multifacetado na capacidade de ser metáfora e metonímia" além de que, ele também pode ser um "veículo para a elaboração de ideias sobre o parentesco".

${ }^{16}$ A partir de um modelo quaternário, a escola hipocrática levava em consideração o equilíbrio dos quatro humores. "O conceito de humor (khymós, em grego), na escola hipocrática, era de uma substância existente no organismo, necessária à manutenção da vida e da saúde" (REZENDE, 2009: 50). Estes humores eram divididos em quatro substâncias: sangue, fleuma, bile amarela e a bile negra.
} 
(2009), ainda tem seus ecos na biomedicina moderna ocidental. De certa forma, esse esquema dos humores e fluídos, inspirado nos filósofos gregos, com maior ou menor intensidade transpassa muitas das teorias e interpretações das substâncias no parentesco ${ }^{17}$. Meu esforço tem sido o de considerar uma ampliação das possibilidades, acatando, como Carsten (2011b) sugere, a fungibilidade e transmissibilidade das substâncias, assim como elementos diferentes que uma substância pode conter, singularizando-a contextualizando-a. Um sangue pode conter o carregado, a reima, partículas de LDL, HDL, ancestralidade, memória e personalidade (MARQUES, 2002) além de outras substâncias e partículas cujas possibilidades combinatórias são ainda mais decisivas. Isso permite considerar os ossos, as unhas e o cabelo, assim como as partes duras, os tecidos e não apenas os fluídos como parte do rol das substâncias, como sugere Janet Carsten. Mas, será que nanopartículas, como variações patogênicas no DNA, também podem ser consideradas como uma espécie de substância? São partículas que o sangue também carrega?

\section{Parte das partes e o todo: substância e DNA}

Como um tipo de força vital transmitida de uma pessoa a outra, sequências de DNA são os traços ancestrais de conexões entre as gerações, evidência material que as características apenas existem como resultados dos relacionamentos. (STRATHERN, 1970: 42-3, tradução do autor) ${ }^{18}$

As reflexões sobre o sangue e as substâncias em seu aspecto material e metafórico têm me acompanhado também no atual projeto de pesquisa de pós-doutorado que iniciei recentemente. Em um contexto bastante diferente do anterior, pretendo pensar as relações de parentesco entre moradores do sul e do sudeste brasileiro, portadores de uma mesma variante patogênica. Variações patogênicas no código genético, conhecidas popularmente como mutações, quando ocorrem são encontradas em todas as células do corpo, inclusive no sangue. Em boa parte dos casos de síndromes genéticas causadas por variantes patogênicas, tais variações podem ter origem hereditária que pode ser desvendada através de exames de rastreamento genético. No entanto, algumas pessoas podem não herdar uma mutação, elas são os primeiros membros de suas famílias a manifestar uma variante patogênica, sendo chamados esses casos pelos geneticistas de "de novo". $\mathrm{O}$ projeto de pesquisa que venho construindo nos últimos meses e que se encontra em fase de levantamento bibliográfico versa sobre as relações entre pessoas ligadas a um mesmo "de novo" ou um mesmo ancestral, nascido provavelmente no final do século XVIII no Brasil. Esta pessoa teria transmitido aos seus descendentes uma variação patogênica que predispõe a uma síndrome rara conhecida como a síndrome Li- Fraumeni.

Esta síndrome, de Li-Fraumeni, foi descoberta no final da década de sessenta pelos médicos Frederick Li e Joseph Fraumeni que identificaram esta variação patogênica no gene TP53. Sendo este gene "o maior supressor de tumores" em

\footnotetext{
${ }^{17}$ Esta questão também faz um paralelo com a comensalidade, sistema de residência e outros aspectos do parentesco que foram trabalhados conjuntamente no quinto e sexto capítulo da minha tese, onde discuti este problema de forma mais exaustiva.

${ }^{18}$ Original: "Like a sort of life-force transmitted from one person to another, DNA sequences are the ancestral traces of connections between the generations, material evidence of the fact that features exist only as the outcome of relationships.”
} 
não-humanos e em humanos, "a principal característica da síndrome está no desenvolvimento de múltiplos tumores ${ }^{19}$ nos portadores ao longo da vida", "com estimativas de que até $90 \%$ dos portadores desenvolverão algum câncer" (ACHATZ et al, 2009; GIBBON, 2013). A Li-Fraumeni não é uma síndrome exclusiva do Brasil, sendo encontrada em outros países, com sua ocorrência nas populações atingidas, de acordo com Achatz (2007) de 1:5000. Já no caso brasileiro, como a autora ressalta, a Li-Fraumeni apresenta uma particularidade: sua prevalência é de 1:300 especialmente nos estados do sul e do sudeste brasileiros. No Brasil,esta síndrome também está relacionada a outra especificidade, que é a existência de uma variante patogênica singular que tem sido atribuída a um mesmo ancestral apical ${ }^{20}$, ou seja, o ancestral mais remoto que as pessoas com a mesma variante patogênica compartilham. A hipótese dos geneticistas e dos oncogeneticistas $^{21}$, é a de que um tropeiro teria sido este ancestral apical, explicando assim a distribuição geográfica dos casos nas regiões sul e sudeste, principalmente nas cidades que faziam parte do percurso realizado pelos tropeiros (ACHATZ, et al 2007; GARRITANO et al 2009).

Um dos meus interesses principais com a atual pesquisa é pensar as relações de parentesco, de solidariedade e de amizade que se estabelecem entre os portadores através da descoberta desta síndrome, com uma atenção especial para essa variação patogênica específica. Um primeiro lugar de encontro entre eles é através da Associação, que está ligada às outras associações da mesma Síndrome pelo mundo. A associação tem como objetivo reunir, amparar e informar os portadores e familiares sobre a síndrome, assim como promover as reuniões, que acontecem no mínimo uma vez por ano na cidade de São Paulo. Ela integra pacientes, familiares, biomédicos, pesquisadores e profissionais da saúde visando o diálogo e fomentando novas pesquisas. Na antropologia, há uma importante trajetória de estudos com associações e coletivos de pacientes e familiares (RABEHARISOA e CALLON, 2002; ROSE, 2013; GRUNDZENSKI, 2013; AURELIANO, 2018; GIBBON, 2011; GIBBON et al., 2012; VALLE, 2013) mostrando que as associações, além de oferecerem uma rede de apoio e ativismo, possibilitam também a "socialização do paciente e da doença" (RABEHARISOA, 2006: 567-8).

No caso da síndrome de Li-Fraumeni, não é apenas a Associação que estabelece vínculos entre os portadores, mas as novas biotecnologias e os marcadores genéticos. Beltrão et al. (2012) consideram que esses fatores interligam-se "na intensa produção de processos de subjetivação, esse ponto que ressoa perspectivas como a de biossocialidade de Paul Rabinow (1992), Gibbon et Novas (2008) [...] ou aquela da " cidadania genética de Heath, Rapp e Taussing (2007)" (BELTRÃO et al., 2012: 5). Na década de noventa do século passado, inspirado nas discussões em torno do biopoder de Michel Foucault, Paul Rabinow (1996) passa a usar o termo biossocialidade para dialogar com as novas identidades e socialidades $^{22}$ que o desenvolvimento da genética, especialmente o projeto Genoma Humano, que naquela época estava na metade (1990-2003), poderia desencadear.

\footnotetext{
19 Segundo Birch et al (1994), os tumores incluem nos casos das crianças, câncer adrenal e no cérebro; para os adolescentes e jovens adultos são comumente observados sarcomas ósseos e nos tecidos moles e nos adultos, câncer de seio, fígado e pulmão.

${ }_{20}$ De acordo com o glossário de parentesco publicado pela revista l' Homme (2000), a definição de ancestral apical, "l' ancêtre apical" é o "ancestral da geração mais antiga que um ou mais indivíduos têm em comum; o ancestral de referência." [Tradução do autor] (L' HOMME, 2000: 722). (Original)“Ancêtre de la génération la plus ancienne qu'ont en commun deux ou plusieurs individus ; l'ancêtre de référence."

${ }^{21}$ Gibbon (2013) chama atenção para o nascimento e fortalecimento do campo da oncogenética no Brasil, especialmente vinculado aos grupos de pesquisa estrangeiros interessados nas "particularidades" que a população brasileira, em razão de sua composição oferece.

${ }^{22}$ Gibbon e Novas (2008) sublinham, sobre o conceito de biossocialidade, que existem "três principais frentes", sendo elas "o reenquadramento da discussão natureza/cultura; emergência das práticas identitárias e abordagem heurística para examinar os novos desdobramentos da investigação científica” (GIBBON e NOVAS, 2008:12)
} 
Seguindo o autor:

É o que eu compreendo por biossocialidade. Eu não discuto a hipótese de um gene da agressão ou do altruísmo. Mas, não é difícil imaginar um grupo formado em torno do cromossomo 17, com uma variante de alelo no lugar 16256 ao invés do 654376 e uma substituição de guanina. (RABINOW, 2010: 19, tradução do autor) ${ }^{23}$

Naquela época, e munido do conceito de biossocialidade, Rabinow de alguma forma antecipa a possibilidade de "um grupo se formar em torno da partilha do cromossomo 17, com uma variação de um alelo", como vemos acontecendo atualmente com os grupos e associações de portadores de variantes patogênicas específicas, sendo elas causadoras de condições distintas nos corpos e síndromes. Além da biossocialidade, outro conceito que me inspira e que compõe a formação de novas subjetividades (ROSE, 2013) é a noção de "molecularização" e de "impressão digital molecular" empregado por Monteiro (2007) e Monteiro e Venâncio (2012). Como resposta aos avanços da genética e da biomedicina, a "impressão digital molecular" marca a singularidade do indivíduo, reforçado pelos biomarcadores genéticos:

\begin{abstract}
A impressão digital, fruto dessas buscas, impôs-se até hoje como forma objetiva de marcar o indivíduo como único e inconfundível. Uma impressão digital molecular, além de marcar o indivíduo, permitindo uma diferenciação inquestionável deste em relação a todos os outros, permitiria, em potencial, a manipulação dessas características, deslocando a lógica da classificação que herdamos do século XIX. (MONTEIRO, 2007: 38)
\end{abstract}

Para Monteiro (2007), essas noções fazem parte das "traduções do corpo para termos moleculares e genéticos". Tais fragmentações, que surgem dos avanços da biologia molecular, como os testes genéticos e os biomarcadores, influenciam nas formas de compreender identidades, corpo, risco, predisposição. Além disso, e mais importante para essa discussão, a genética moderna não afeta somente o indivíduo, sendo um exemplo as novas abordagens sobre o parentesco, identidade e as relações com os ancestrais. Kaja Finkler (2001) mostra que o parentesco americano - ou euroamericano -, por tratar-se de um sistema de descendência bilinear, aceitou bem as noções de transmissão e hereditariedade preconizadas pela biomedicina e genética moderna. Para autora, a bilinearidade teria um papel facilitador na "medicalização das famílias", que passam, a partir do pressuposto do parentesco biológico e da transmissão, a considerar "históricos médicos familiares" e variantes patogênicas transmissíveis nas consultas. Mas, igualmente, na busca por contato e informações, as famílias passam a reunir seus membros em torno da ideia de risco e predisposição genéticas à doenças.

Esta habilidade que o DNA possui para reagrupar e socializar pessoas com um vínculo biogenético de parentesco, ligados pelas figuras dos "True biological Ancestors" (FINKLER, 2001: 249), seria ainda mais evidente em sua função de "repositório central de memória". Para Finkler, além da possibilidade de traçar ancestralidades e reativar memórias e laços familiares, o DNA estabeleceria uma continuidade com os mortos, sendo ele no final das contas uma "partícula oca" não contendo nenhum efeito na memória direta familiar.

Tendo a concordar em muitos pontos com Finkler, como sobre a forma pela qual o sistema euroamericano englobou a noção de ancestralidade e verdade ge-

${ }^{23}$ Original: «(...). C'est ce que j'entends par biosocialité. Je ne discute pas l'hypothèse d'un gène de l'agression ou de l'altruisme. Mais il n'est pas difficile d'imaginer un groupe formé autour du chromosome 17, avec une variante d'allèle au lieu 16 256, site 654376 et une substitution de guanine.» 
nética e, especialmente, concordo que o DNA pode ser uma partícula aglutinadora de parentesco, de biosocialidade e de fragmentos de memória e história familiar, tal como outros autores, como Rabinow, já aventaram. Contudo, neste atual exercício de considerar o conteúdo genético (genes, variações patogênicas, DNA) enquanto substância, diferentemente de Finkler, eu avento aqui a hipótese que ele não teria um esvaziamento, sendo seu conteúdo mutável e maleável dentro do parentesco. Seriam partículas que transbordam em substância, que as compõe e que são mutáveis segundo as possibilidades de relacionalidade com outras substâncias, comensalidade, emoções e imaginação, por exemplo. Não se separam do sangue e outros fluídos, nem como substância biogenética ou metáfora. Algumas pistas nesta direção podem ser encontradas em um trabalho de Sarah Gibbon (2013) sobre câncer hereditário no Brasil. Neste artigo, contemplando tanto interlocutores com casos na família ou mesmo portadores de Li-Fraumeni e de outras variantes que predispõe ao câncer, como BRCA1 e BRCA2, Gibbon observa que a noção de risco e de predisposição ao desenvolvimento da doença ou de herdar a variante passam por outras variáveis. Alguns interlocutores ligaram, por exemplo, o risco genético com um trauma que ancestrais teriam passado. Outros, consideraram importantes fatores como somatização, ansiedade e, até mesmo, figuram alimentação e outras práticas que interfeririam na transmissão e herança de tais genes.

Estes conceitos me levam a pensar que as relações de parentesco no caso da síndrome de Li- Fraumeni no Brasil podem ser um espaço privilegiado para aprofundar mais os estudos sobre transmissão (hereditariedade, características e variantes), memória genealógica e genética, além da noção de substância. Uma das hipóteses que permeia a reflexão sobre o parentesco nesta síndrome é que, diferentemente de outras variantes patogênicas hereditárias já estudadas, igualmente responsáveis pelo câncer genético, como por exemplo BRCA1 e BRCA2, no caso brasileiro, há a presença de um ancestral apical comum para os portadores. Neste caso, a proximidade entre os portadores é ainda mais estreitada. Em outras variantes patogênicas hereditárias que predispõe ao câncer, as pessoas ao descobrirem possuí-la se veem relacionadas, de uma maneira mais distante, como pertencentes a um grupo específico. Contudo, ter um mesmo ancestral apical, além da variante patogênica, estabelece também uma relação ou a possibilidade de um parentesco longínquo a partir de um indivíduo histórico que inter-relaciona seus descendentes.

Podemos traçar um paralelo da figura do tropeiro com um ancestral que remete a algo muito próximo do paradoxo do "parente famoso" que Schneider (2016) nos apresenta. No caso do parente famoso, os colaterais próximos ao ego muitas vezes não são conhecidos e mencionados; enquanto o parente famoso, mesmo estando a uma distância genealógica muito maior, o é pelos interlocutores. No entanto, este parente é apresentado aos portadores através de testes, de marcadores genéticos apresentados como nano frações do genoma de cada um dos aparentados conectados entre si por resultados explicados através do discurso biomédico. Há uma negociação entre a memória genealógica e a memória genética, preenchendo de sentidos e sendo atualizadas por lados diversos. 


\section{Considerações finais}

É possível considerar que muitas coisas transitem e sejam incorporadas ao sangue, sejam elas substâncias que remetem ao parentesco - que vão além daquelas biogenéticas -, ou nas plurais materialidades e metáforas que ele pode carregar. Esta tem sido minha busca, em que o "carregado" no sangue e as variantes patogênicas se entrelaçam embasando meus questionamentos sobre o parentesco sem uma homogeneidade fluídica do sangue. A forma como ele "corre" e como transmite; as formas e elementos que transitam dentro podem ser substâncias e componentes dessas substâncias. Talvez neste ponto, deva considerar a presença da variante patogênica de forma próxima da polissemia do sangue e do DNA que Leal (2014) nos mostra, em que o sangue ocupa um lugar "equivalente da genética, tratado como substância corporal, uma fonte biomédica e também metáfora" (LEAL, 2014: 231-2). Sangue e DNA, enquanto substâncias que podem conter frações e componentes e, ao mesmo tempo, serem frações e componentes, nesta ambivalência permitem, de certo modo, através desta retro-interação, múltiplas formas de elaborar e pensar o parentesco.

Para alguns autores, o sangue vai ceder lugar ao discurso da biologia molecular moderna e da biomedicalização do parentesco. Esta é a posição de Howell (2009), que aposta na substituição gradativa dos saberes biogenéticos sobre as metáforas e alusões à filiação. Finkler (2001), falando da diferença da substância biogenética e do DNA mostra que se trata de uma passagem do "visível para o invisível". No entanto, como mencionado anteriormente sobre as características do sangue para Carsten, o DNA não é vermelho, nem impressionante e nem de fácil visibilidade - ao menos a olho nu - tal como o sangue é. Se de certo modo ele escapa - ao menos até o momento - de ser associado com sendo composto ou interagindo com outros pares, como o sangue dos peixes ou da carne do porco que pode participar do sangue das pessoas, por outro, ele permite tal como o sangue a possibilidade de ser imaginado em partes e componentes. É importante lembrar que ambos - sangue e DNA - têm a mesma potência de ligar o presente com o passado, sendo metáforas e materialidades para a ascendência, identidade e pertencimento. Possivelmente, podem ser compostos e fragmentários enquanto substâncias.

Este artigo, buscou realizar um exercício de imaginação que está longe de ser conclusivo. Ainda falta muita etnografia para saber se as partículas e outros pedaços de materiais e imateriais no sangue - do carregado às variantes patogênicas- somam-se às substâncias no parentesco. Gosto de pensar que estou procurando um parentesco "particular" em substâncias não-homogêneas, em que nano partículas em sua materialidade ou metáfora podem formar parentes, orientar genealogias e, principalmente, estabelecer relações. No mesmo sentido, continuarei a me questionar sobre os fragmentos, substâncias e componentes que o sangue carrega e que tornam possível uma infinidade de relações, entre elas as de parentesco. 


\section{Referências}

ACHATZ, Maria Isabel Waddinton. Modificadores de penetrância de mutação germinativa no gene TP53 em famílias brasileiras com diagnóstico clínico da síndrome de Li-Fraumeni e Li-Fraumeni like :impacto dos polimorfismos intragênicos do TP53 e de genes que regulam a atividade da p53. tese Doutorado. Faculdade de Medicida, Universidade de São Paulo, 2008

ACHATZ, Maria Isabel Waddington; OLIVIER, Magali; LE CALVEZ, Florence et al. The TP53 mutation, $\mathrm{R} 337 \mathrm{H}$ is associated with Li-Fraumeni and Li- FraumeniLike syndromes in Brazilian families. Cancer Letters, 245, 2007.

ACHATZ, Maria Isabel Waddington; HAINAUT, Pierre; ASHTON-PROLLA, Patricia. Highly prevalent TP53 mutation predisposing to many cancers in the Brazilian population: a case for newborn screening? Lancet Oncology, 10: 920925, 2009.

ALLARD, Olivier. La parenté en substances. La critique de Schneider et ses effects. L'Homme, 2006: 177-178.

AURELIANO, Walesca. Trajetórias Terapêuticas Familiares: doenças raras hereditárias como sofrimento de longa duração. Ciência e Saúde Coletiva, 23 (2), 2018

BATISTONE, Maíra Silva. Consumo alimentar na comunidade caiçara do Bonete em Ilhabela. Tese de Doutorado em Biologia e Ecologia, UNICAMP, São Paulo, 2006.

BIRCH, A.; CROWTHER, D.; et al. Prevalence and diversity of constitutional mutations in the p53 gene among 21 Li-Fraumeni families. Cancer Res. 54 (5): 1298304, 1994.

CANESQUI, Ana Maria. Antropologia da alimentação. Revista de Saúde Pública, 22 (3): 207-216, 1988.

CARSTEN, Janet. Culture of Relatedness: new approaches to the study of kinship. Cambridge University Press, 2000.

CARSTEN, Janet. Substance and Relationality: blood in contexts. The Annual Review of Anthropology, 40, $2011 \mathrm{a}$.

CARSTEN, Janet. La vie sociale du sang (Penang, Malasie). Revue Terrain d'Ethnologie d'Europe, 56, 2011b.

CARUSO, Juliana P. Lima. Consubstancialidade, sangue e parentesco: algumas reflexões sobre substâncias. XI RAM-Diálogos, práticas y visiones antropológicas desde el Sur, Montevideo, 2015.

CARUSO, Juliana P. Lima. De l'autre côté de l'île. Parenté et identité dans sept communautés caiçaras du Sud-est brésilien. Anthropologie. École doctorale EPHE-École Pratique des Hautes Études. Mention RSP. France, 2017.

BARRY, Laurent; BONTE, Pierre; D' ONOFRIO, Salvatore; GOVOROFF, Nicolas, JARMAND, Jean-Luc; MATHIEU, Nicole-Claude; PORQUERES I GENÉ, Enric; WILGAUX, Gerome; ZEMPLENI, András; ZONABEND, Françoise. Glossaire de la parenté. L'homme, 2000: 154-155. 
BELTRÃO, Jane F; GIBBON, Sahra; SANTOS, Ricardo V. (orgs.) Identidades emergentes, genética e saúde: perspectivas antropológicas. Rio de Janeiro: Garamond/Fiocruz, 2012.

EIDEIMAN, Jean-Sébastien. Les anthropologues et l'idéologie du sang: Comment définir la famille? Informations sociales, 139 (3) : 66-77, 2007.

FINE, Agnès.Retour critique sur l'inceste de deuxième type. L'Homme, 205, 2013 .

FINKLER, Kaja. The Kin in the Gene: The Medicalization of Family and Kinship in American Society. Current Anthropology, 42 (2): 235-263, 2001.

FORTIER, Corine. Le lait, le sperme, le dos. Et le sang? Journal d'études Africains, 2011

GARRITANO, Sonia; GEMIGNANI, Frederica; PALMERO, Edenir; OLIVIER, Magali et al. Detailed haplotype analysis at the TP53 locus in p.R337H mutation carriers in the population of Southern Brazil: evidence for a founder effect. Human Mutation: Variation, Informatics, and Disease. Wiley Online Library, 2009.

GIBBON, Sahra; NOVAS, Carlos. Biosocialities, genetics and the social sciences: Making biologies and identities. London: Routledge, 2008.

GIBBON, Sahra. E. Ancestry, temporality and potentiality: engaging cancer genetics in Southern Brazil. Current Anthropology, 54 (supl. 7), 2013

GIBBON, Sahra. E. Family medicine,-'La Herencia' and breast cancer: understanding the (dis)continuities of predictive genetics in Cuba. Social Science \& Medicine, 72 (11): 1784-1792, 2011.

GRUDZINSKI, Roberta Reis. A nossa batalha é fazer o governo trabalhar: etnográfico acerca das práticas de governo de uma associação de pacientes. Dissertação em Antropologia. UFRGS, Porto Alegre, 2013.

HAMDANI, S. Filiation par l'allaitement. La revue lacanienne, 8 (3): 103-112, 2010.

HÉRITIER, Françoise. Les deux sœurs et leur mère: anthropologie de l'inceste. Paris: Edition Odile Jacob, 1994

HOWELL, Signe Lise. La voix du sang: adoptés et immigrés dans les discours sur la biologie et la culture. Ethnologie française, 39 (2): 331-339, 2009.

HUTCHINSON, Sharon E. "Identity and substance: the broadering bases of relatedness among the Nuer of southern Sudan”. In: CARSTEN, Janet (org.). Cultures of relatedness: New approaches to the study of kinship. Cambridge University Press, 2000.

KLAPISCH-ZUBER, Christiane. Parents de sang, parents de lait : la mise en nourrice à Florence (1300-1530). Annales de démographie historique 1983 (Mères et nourrissons). Paris : EHESS, 1984. pp. 33-64.

LÉVI-STRAUSS, Claude. As estruturas elementares do parentesco. Petrópolis: Vozes, 2009 [1949].

LEAL, Natacha Simel. Nome aos bois: zebus e zebuzeiros em uma pecuária brasileira de elite. Tese em Antropologia. Departamento de Antropologia/PPGAS, Universidade de São Paulo, 2014. 
MARQUES, Ana Claudia. Intrigas e questões. Tramas sociais no Sertão de Pernambuco. Rio de Janeiro: Relume Dumará, 2002.

MONTEIRO, Marko S. A.; VÊNCIO, Ricardo Z. N. "A 'molecularização' do câncer de próstata: reflexões sobre o chip de DNA”. In: Identidades emergentes, genética e saúde: perspectivas antropológicas. Rio de Janeiro: Garamond/Fiocruz, 2012.

MONTEIRO, Marko S. A. Os dilemas do humano: reinventando o corpo em uma era (bio) tecnológica. Tese de Doutorado em Ciências Sociais, Universidade Estadual de Campinas, UNICAMP, 2005

MORGAN, H. Lewis. Systems of Consanguinity and Affinity of the Human Family; Washington: Smithsonian Institution, 1871.

MAUÉS, Raimundo H.; MAUÉS, Maria Angélica Motta. O modelo da 'reima'. Representações alimentares em uma comunidade amazônica. Anuário Antropológico, 77: 120-47, 1978.

NICOLAS, Jonas, Marie-Clémence Le Pape, et Bérangère Véron. Au nom du sang: amour et filiation. À l'épreuve de contextes en évolution. Informations sociales, 144 (8): 100-107, 2007.

PEIRANO, Mariza Gomes e Souza. Proibições alimentares numa comunidade de pescadores (Icaraí, Ceará). Dissertação de Mestrado em Antropologia Social, Universidade de Brasília, 1975.

RABEHARISOA, V.; CALLON, M. L'engagement des associations de malades dans la recherche. Revue internationale des sciences sociales, 171 (1): 65-73, 2002.

RABEHARISOA, Volona. From representation to mediation: The shaping of collective mobilization on muscular dystrophy in France. Social Science \& Medicine, 62, 2006.

RABINOW, Paul. L'artifice et les Lumières: de la sociobiologie à la biosocialité, Politix, 90 (2): 21-46, 2010.

RABINOW, Paul. "Artificiality and enlightenment: From sociobiology to biosociality". In: Essays on the Anthropology of Reason. Princeton: Princeton University Press, 1996. pp. 91-112.

REZENDE, Joffre Marcondes. À sombra do plátano: crônicas de história da medicina. São Paulo: Editora Unifesp, 1999. pp. 49-53.

ROSE, Nikolas. A política da própria vida: biomedicina, poder e subjetividade no século XXI. São Paulo: Paulus, 2013.

SCHNEIDER, David M. Parentesco Americano: uma exposição cultural. Coleção Antropologia. Petrópolis: Vozes, 2016.

SCOPEL, Raquel Paiva Dias. A cosmopolítica da gestação, parto e pós-parto: Munduruku. Tese de Doutorado, Programa de Pós-Graduação em Antropologia Social, UFSC, 2014

SILVA, Andréa Leme da. Comida de gente: preferências e tabus alimentares entre os ribeirinhos do Médio Rio Negro (Amazonas, Brasil). Revista de Antropologia, 50 (1): 125-179, 2007. 
STRATHERN, Marilyn. O Gênero da dádiva: problemas com as mulheres e problemas com a sociedade na Melanésia. Campinas: Ed. Unicamp, 2006.

STRATHERN, Marilyn. Property, Substance and affect: Anthropological essays on persons and things. London and New Brunswick: The Athlone Press, 1999.

WOORTMAN, K. Quente, frio e reimoso: alimentos, corpo humano e pessoas. Caderno espaço feminino, 19, 2008.

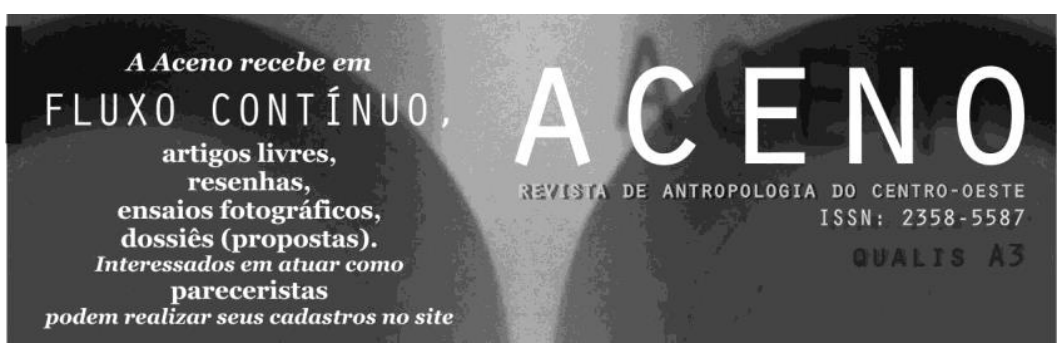




\section{A

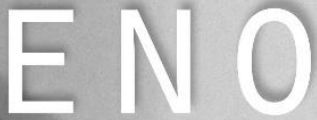 \\ REVISTAA DE ANTROPOLOGIA DO CENTRO-OESTE}

CHAMADA DE ARTIGOS

DOSSIE TEMÁTICO:

EPISTEMOLOGIAS, METODOLOGIAS E QUESTÕES

ETICAS EM PESQUISAS COM ABORDAGENS

EM DIVERSIDADES SEXUAIS E DE GENERO

(v. 8, N. 16, 2021)

COORDENADORXS:

ESTEVÃo FERNANDES (UNIR, PPGAS/UFMT)

MARIANE PISANI (UFT)

MOISES LOPES (PPGAS/UFMT)

VOLUME 8

Simone de OLIVEira Mestre (UNifal-MG, PPGS/UFMG)

ste dossiê busca congregar pesquisas e reflexões em torno das

- diversidades sexuais e de gênero, com especial foco nos debates 1 respeito de outras possibilidades de desenvolvimento de investigações que problematizem o ponto de vista teórico-metodológico e ético constituído a partir da história colonial do Ocidente. Neste sentido, buscamos contribuições que dialoguem com os estudos feministas, LGBTs, com as leituras pós-coloniais, teoria queer e/ou tomem como ponto de discussão as epistemologias, metodologias e questões éticas que envolvam pesquisas com abordagem em diversidades sexuais e de gênero. Muito já se tem escrito sobre a necessidade de descolonizar essas abordagens, seja a partir de uma "epistemologia cucaracha" de uma "teoria cú" (PELÚCIO, 2014); do "queer decolonial" (PEREIRA, 20I5); do "queer caboclo" (FERNANDES e GONTIJO, 2016) ou mesmo das discussões que envolvem o feminismo decolonial (GONZALEZ, 1988; LUGONES, 2008; SEGATO, 2013): todas essas reflexões se tornaram relevantes e

fundamentais para compreensão das questões que envolvem as diversidades sexuais e de gênero no chamado Sul Global. Desse modo, neste dossiê, buscamos provocar diálogos que rompam com uma visão heterocentrada, falogocêntrica, metropolitana, normativa e colonizadora das diversidades

PRAZO FINAL

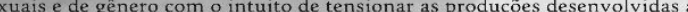

DE SUBMISSÃO: partir das realidades brasileiras e latino-americanas, buscando um

30 DE JANEIRO mpliação crítica e perturbadora do status quo dessas investigações. Assim, que possibilitem tanto a exploração de temas e problemas já consolidados pelo campo de estudos sobre diversidades sexuais e de gênero quanto - e principalmente - sua ampliação. 